\title{
A honvédelmi törvény védelmi igazgatást érintő, 2020. január 1-jén hatályba lépett módosításai, különös tekintettel a védelmi bizottságokat érintő módosításokra
}

\section{Amendments of the National Defence Act concerning Defence Administration, Coming into Force on January 1, 2020, with Special Regard to Amendments concerning Defence Committees}

\section{Absztrakt}

Modern kori világunkban a felgyorsult események és folyamatosan változó jelenségek kihatással vannak a jogszabályalkotás területére is. A rohamos tempójú globális és hazai változások szükségessé teszik a meglévő jogi szabályozások felülvizsgálatát és jogszabályaink módositását. A honvédelmi kérdésekkel összefüggésben 2019. év folyamán indokolttá vált a szabályozásnak a felmerült és hangsúlyossá váló követelményekhez való igazítása. Ennek a folyamatnak az eredményeképpen 2020. január 1-jén sor került a honvédelmi törvény módosítására.

A szerző ebben a cikkben megvizsgálja, hogy milyen elözmények, szabályozási szükségszerüségek indokolták a honvédelmi törvény módositását. Saját szempontrendszer alapján - kategorizálva az egyes módosító rendelkezéseket -általános, átfogó képet ad a törvényi szabályozás változásairól. Kiemelten vizsgálja a védelmi igazgatás rendszerét, azon belül a megyei és helyi védelmi bizottságok szervezeti és feladatrendszerét érintö módosításokat. Célja, hogy rámutasson a szabályozás pozitív vonásai mellett az esetleges ellentmondásokra, hiányosságokra, ezzel megfontolandó felvetéseket szolgáltatva a későbbi alacsonyabb szintü szabályozás során azok megszüntetéséhez. 
Kulcsszavak: honvédelmi törvény módositása, honvédelmi kérdésekkel összefüggő módositás, védelmi igazgatás, megyei védelmi bizottságok, helyi védelmi bizottságok

\begin{abstract}
In our modern world, accelerated events and ever-changing phenomena also have an impact on legislation. The rapid-paced global and domestic changes necessitate the review of the existing legal regulations and the amendment of our legislation. In connection with defence issues, during the year 2019 it has become justified to adapt the regulations to the requirements that have arisen and have become more emphasised. As a result of this process, the National Defence Act was amended on January 1, 2020. In this article, the author examines the antecedents and regulatory necessities that have justified the amendment of the National Defence Act. Based on its own system of criteria - through categorisation of the amending provisions - it gives a general, comprehensive picture on the changes in the legal regulations. It focuses on the changes in the system of the defence administration, including the amendments in the organisation and task system of the county and local defence committees. In addition to highlighting the positive features of the regulation, its aim is to point out the possible contradictions and shortcomings, thereby providing suggestions to be considered during the subsequent lower-level regulation in order to eliminate them.
\end{abstract}

Keywords: amendment of defence act, amendment related to defence issues, defence administration, county defence committees, local defence committees

\title{
1. Bevezetés
}

A biztonsági környezet változása hazánkban is felgyorsította a védelmi igazgatással kapcsolatos tudományos kutatásokat, így többek között középpontba került a védelmi bizottságok rendeltetésének, múködésének és az ezzel kapcsolatos gyakorlati kérdéseknek az elemzése is.

Az elmúlt időszakban folyó kutatások kitértek a védelmi igazgatás honvédelmi igazgatással való összefüggéseire, a védelmi rendszer komplexitásának vizsgálatára stb., ${ }^{2}$ de értelemszerüen nem foglalkoztak a napjainkban folyó jogszabályváltozásokkal és az ezzel kapcsolatos gyakorlati kérdésekkel.

Hornyacsek Júlia: A védelmi igazgatási feladatok rendszere, a végrehajtás személyi, technikai feltételei, lehetséges módszerei, eszközei. In Hornyacsek Júlia (szerk.): A védelmi igazgatás müködésének gyakorlati tapasztalatai napjaink kihivásainak tükrében. Budapest, Dialóg Campus, 2019. 87-99.; Lakatos László: A honvédelmi típusú különleges jogrendek életbeléptetését igénylő helyzetek és azok korszerü gyakorlati megoldása. In Hornyacsek Júlia (szerk.): $A$ védelmi igazgatás müködésének gyakorlati tapasztalatai napjaink kihívásainak tükrében. Budapest, Dialóg Campus, 2019. 37-60.; Muhoray Árpád: A katasztrófavédelem hivatásos és civil ágának fejlődése, feladatai a védelmi igazgatásban. In Hornyacsek Júlia (szerk.): A védelmi igazgatás fö területeinek változásai az elmúlt időszakban, és a fejlesztés lehetséges irányai. Budapest, Nemzeti Közszolgálati Egyetem, 2019. 59-71.; Keszely László: A védelmi igazgatás fejlődési irányai 1989-től napjainkig és lehetséges fejlesztési irányai az átfogó megközelítés szempontjából. In Hornyacsek Júlia (szerk.): A védelmi igazgatás rendszere és a honvédelmi igazgatással való kapcsolatának elméleti és gyakorlati összefüggései. Budapest, Dialóg Campus, 2019. 9-28. 
Mára számos olyan globális és hazai szintű tényező, folyamat, jelenség jelent meg, került előtérbe Magyarországon, amely felvetette a honvédelmi törvény ${ }^{3}$ módosításának szükségességét. Ezeknek a törvényi szintü szabályozást igénylő kérdéseknek a rendezése érdekében a Kormány megtárgyalta, elfogadta és 2019. november 12-én benyújtotta az Országgyúléshez a honvédelmi törvényt módosító T/8029. számú törvényjavaslatát, ${ }^{4}$ majd az Országgyülés a törvényalkotás folyamatát követően 2019. december 10-én elfogadta a 2019. évi CV. törvényt az egyes törvények honvédelmi kérdésekkel összefüggő módosításáról. Az Országgyűlés elnöke, valamint a köztársasági elnök aláírását követően 2019. december 16-án sor került a törvény kihirdetésére,$^{5}$ amely 2020. január 1-jei hatállyal beemelte a honvédelmi törvénybe a rögzített módosításokat. ${ }^{6}$

A módosítások több területet érintettek, így a hibrid fenyegetésekkel szembeni fellépést, a katonai kibertérműveletekkel kapcsolatos feladatrendszert, a kritikusinfrastruktúra-védelemmel kapcsolatos feladatokat. A jogalkotó új jogintézményeket is beemelt a törvénybe, mint például a honvédelmi bírság jogintézményét, a honvédelmi referens intézményét, illetve számos rendelkezés érintette a védelmi igazgatás, ezen belül a megyei és helyi védelmi bizottságok szervezet- és feladatrendszerét is.

\section{A honvédelmi törvény módosításának legfontosabb okai}

Korábban, 2019. január 1-jei hatállyal sor került a honvédelmi törvény módosítására. A módosítások közül az egyik legjelentősebb a honvédelmi tárca és a Magyar Honvédség $(\mathrm{MH})$ integrációjának megszüntetésével a honvédelem irányítási és vezetési rendszerének átalakítása volt. Ennek következtében 2019. január 1-jétől a Honvédelmi Minisztérium (HM) hatás- és jogkörébe az irányítói, a kontroll- és a közigazgatási feladatok, míg a MH Parancsnoksága - amely a HM Honvéd Vezérkar és a MH Összhaderőnemi Parancsnokság összevonásával jött létre - hatás- és jogkörébe a katonai feladatok vezetése és azok végrehajtása került. Ezzel megvalósult az elsősorban politikai és közigazgatási szakértelmet igénylő irányítás és a katonai szakmai tudást követelő vezetés határozott elkülönülése. A honvédelmi tárca továbbra is végzi a honvédelem kormányzati szintü kidolgozó, irányító és koordinációs feladatait, míg a Parancsnokság a Honvédség katonai felső szintű tervező, szervező és katonai tevékenységének vezető szerveként müködik. ${ }^{7}$

A HM és a MH szétválasztásával felmerült az igény a tárca és az MH Parancsnoksága közötti koordináció megteremtésére, amelynek érdekében sor került a honvédelmi államtitkári tisztség létrehozására. A korábban a közigazgatási államtitkár irányítása alatt működő HM Védelmi Igazgatási Főosztály a honvédelmi államtitkár irányítása alá került, erősítve ezzel a főosztály kormányzati szinten betöltött interface szerepét.

2011. évi CXIII. törvény a honvédelemről és a Magyar Honvédségröl, valamint a különleges jogrendben bevezethető intézkedésekről (Hvt.)

A honvédelmi törvényt módosító T/8029. számú törvényjavaslat.

A honvédelmi törvény módosítása.

Magyar Közlöny, (2019), 205. 8923-8931.

Nyulas Szabolcs: Új alapok, tiszta viszonyok a Magyar Honvédség vezetésében. Honvédelem, 2019. 
A honvédelem vezetési és irányítási rendszerének 2019. évi átalakítása felvetette a honvédelmi törvény ismételt módosításának szükségességét.

A törvény 2020. január 1-jei módosításának másik fontos indokát a biztonsági környezet változása, a hibrid fenyegetések megjelenése és törvényi szintű szabályozásának igénye jelentette. A hibrid hadviselés lényegi vonása a katonai dimenzió mellett az egyre erőteljesebben megjelenő nem katonai - gazdasági, politikai, információs stb. - eszközök alkalmazása megfélemlítéssel, illetve manipulációval, ezért az ellene való fellépés összkormányzati feladatként jelentkezik. A hibrid fenyegetésekkel szemben a társadalom ellenálló képességének (resilience) növelésére van szükség, ehhez pedig a polgári felkészültséget (civil preparedness) kell erősíteni.

Az Észak-atlanti Szerződés Szervezete (NATO) tagjai már 2016. év nyarán kinyilvánították elköteleződésüket a nemzeti ellenálló képességük és ennek érdekében a polgári felkészültség javítása, erősítése mellett. ${ }^{8}$ Ezen célok eléréséhez ${ }^{9}$ a kormányzat, a létfontosságú szolgáltatások folytonosságára, a civil infrastruktúra biztonságára és a katonai erők civil eszközökkel történő támogatására szükséges fókuszálni.10 $\mathrm{A}$ tagállami elköteleződést követően a NATO - a Szövetség egészére kiterjedően - felmérette a tagállamokkal a saját nemzeti ellenálló képességüket, amelynek eredményét ezt követően összegezte és értékelte, majd abból következtetéseket levonva ajánlásokat fogalmazott meg a nemzetek felé. Ezzel segítséget nyújtott ahhoz, hogy meginduljon a polgári felkészültség helyzetének feltérképezése. ${ }^{11}$

A jogszabályi háttér hiányos volta miatt Magyarországon az egyes tárcák között a szükséges intézkedések, feladatok megvalósítása vonatkozásában az érintett hatáskörök és felelősségi körök nem voltak egyértelműen tisztázottak, ezért a megfelelő jogi szabályozottság érdekében 2019. január 1-jétől a jogalkotó - a HM Védelmi Igazgatási Főosztály javaslatára - a honvédelmi törvényben rögzítette a polgári felkészültség nemzeti fogalmát, ${ }^{12}$ amely honvédelmi feladatként jelenik meg. A definíció rögzítése következtében szükségessé vált a honvédelemben közremüködő egyes szervek vonatkozásában a feladatok konkretizálása, ennek következtében a honvédelmi törvény 2020. január 1-jei módosítása során sor került a Kormány, a honvédelmi miniszter, az illetékes miniszter és a megyei védelmi bizottság feladatrendszerében a konkrét feladatok telepítésére. Jelenleg folyamatban van a törvényi szintű fogalomnak a végrehajtási rendeletben történő részletes kidolgozása, amely már a polgári felkészültség követelményeit is fogja tartalmazni. ${ }^{13}$ A NATO komoly hangsúlyt fektet a tagállamok

8 Fontos rögzíteni, hogy az ellenállóképesség és a polgári felkészültség - a NATO álláspontja szerint - elsősorban nemzeti kompetencia, a NATO szerepe e képességek vonatkozásában döntően a segítségnyújtás, a nemzetek támogatása, hozzáadott értéket adva.

9 NATO: Warsaw Summit Communiqué. (Varsói csúcstalálkozó közleménye az Észak-atlanti Tanács 2016. július 8-9-én tartott ülésén.)

10 NATO: Commitment to enhance resilience. (Az állam- és kormányföknek az Észak-atlanti Tanács 2016. július 8-9-én Varsóban tartott ülésén tett nyilatkozata az ellenálló képesség fokozása iránti elkötelezettségükről.)

1 NATO: The Secretary General's Annual Report. (A NATO fötitkár 2018. évi jelentése.) 2018.

12 Hvt. 80. § „28:: polgári felkészültség: a honvédelemben közremüködő szervek honvédelmi feladatai ellátása körében végrehajtott, külön meghatározott követelmények teljesítése érdekében végzett tevékenysége, melynek célja a kormányzat folyamatos működésének biztosítása, és a katonai műveletek polgári képességekkel történő támogatása békeidőszakban, különleges jogrend idején, valamint a válságkezelés katonai feladatai végrehajtása időszakában."

13 Hvt. 81. § (1) bekezdés $\mathrm{x}$ ) pontja alapján a Kormány felhatalmazást kapott, hogy rendeletben állapítsa meg a polgári felkészültség követelményeit. 
védelmi tervezési képességének felmérésére, amelynek során a katonai képességeken kívül egyre inkább a - tagállam védelmi képességének részét képező - polgári felkészültség képességére fókuszál, és követelményként jelenik meg egy integrált civil-katonai terv megléte. Hibrid fenyegetések napi gyakorisággal érik a NATO tagállamait, ezért egy olyan aktuális problémáról beszélhetünk, amellyel szemben a hatékony fellépés - jellegéből adódóan - összkormányzati szintü feladatként jelenik meg, és amelynél döntő szerepe van a koordinációnak. A hibrid fenyegetések folytán új, szerteágazó, összetett feladatrendszerrel egészült ki a NATO-tagállamok védelmi rendszere.

A törvény 2020. január 1-jei módosításának szükségességét vetette fel a kritikusinfrastruktúra-védelem - létfontosságú rendszerek védelme - területe is. A honvédelmi törvénnyel egy időben a létfontosságú rendszerek védelméről szóló törvény ${ }^{14}$ módosítására is sor került. A nemzeti létfontosságú rendszerelemek kijelölése a vonatkozó szabályozás alapján ágazati keretek között történt. Az ország, a lakosság védelme érdekében a hibrid és egyéb fenyegetésekkel szemben felmerült azonban az ágazatokon átívelő, horizontális koordináció igénye, ezért a létfontosságú rendszerek védelméről szóló törvénybe a jogalkotó beemelte, hogy a HM Hatósági Főosztály - mint a honvédelmi rendszerek és létesítmények ágazati kijelölő hatósága - honvédelmi érdekből, honvédelmi kritériumok alapján bármely ágazatnál az adott ágazatba tartozó rendszerelemet nemzeti létfontosságú rendszerelemmé kijelölheti. ${ }^{15}$ Rögzítette a jogalkotó továbbá azt is, hogy a nemzeti létfontosságú rendszerelemek nyilvántartásából az adott nyilvántartó hatóság az illetékes honvédelmi szervezeteknek - a honvédelmi ágazat javaslattevő hatóságának - a lehetséges honvédelmi létfontosságú rendszerelemek körének felmérése céljából adatot továbbíthat. ${ }^{16}$

A szabályozás szükségességét vetették fel a hibrid fenyegetések között megjelenő kiberfenyegetések is. Az infokommunikációs rendszerek védelme a polgári felkészültség egyik meghatározó területét képezi. A jogalkotó a törvény VIII. fejezetében a 40/A alcím alatt „A katonai kibertér müveletekre vonatkozó különös szabályok" címmel részletesen szabályozta a Honvédség katonai kibertér műveleti erői tevékenységét. A szabályozás hivatalos indokolása szerint:

"A rendelkezés igyekszik a NATO elvárásaival és fejlesztési irányaival összehangolt módon, a nemzeti érdekek érvényesítését szavatolva, az egyes kibertér műveleti feladatok körében a fokozatosság, szükségesség és arányosság elvét érvényesítve sajátos szabályozást megfogalmazni a katonai kibertér müveleti képességek igénybevételéhez. Ennek részeként a szabályozás a katonai és szövetségi érdekek, valamint az országvédelem szempontjából közelíti meg a kibertérből érkező fenyegetéseket és támadásokat, és ezekre mint katonai tevékenységekre tekint. A jelzett szabályozás a kibertérben megvalósuló müveletek váratlanságára és valós idejü megvalósulására kíván törvényileg szabályozott reagálási rendszert kiépíteni, amelynek részletszabályait alacsonyabb szinten kell kidolgozni."17

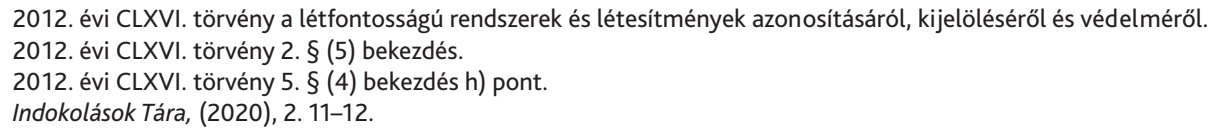


Meg kell még említeni a módosítások okai között, hogy egyes változtatások célja más jogszabályok (például a kormányzati igazgatásról szóló törvény, ${ }^{18}$ az Alaptörvény) rendelkezéseivel való összhang megteremtése, a kollíziók megszüntetése volt.

\section{A honvédelmi törvény módosításairól általánosságban}

A honvédelmi törvény módosításai számos megközelítés ${ }^{19}$ alapján elemezhetők. Ennek egyik lehetséges módja, ha megvizsgáljuk, hogy a kiegészítő, pontosító, korábbi szövegrészek helyett hatályba lépő rendelkezések milyen területeket érintenek. E megközelítési mód alapján megállapítható, hogy a módosítások három csoportba sorolhatók: az elsőbe a hibrid fenyegetésekkel szembeni fellépéssel, valamint a katonaikibertér-müveletekkel kapcsolatos, a másodikba a védelmi igazgatás, azon belül a katonai igazgatás rendszerét érintő rendelkezések, míg a harmadik kategóriába az egyéb területekkel kapcsolatos szabályozás sorolható. ${ }^{20}$

\subsection{A hibrid fenyegetésekkel szembeni fellépéssel, valamint a katonai kibertér müveletekkel kapcsolatos rendelkezések}

A biztonságot veszélyeztető tényezők közül a 21. század egyik legösszetettebb problémáját jelentik a világ országai számára az úgynevezett hibrid fenyegetések, támadások, amelyek kezelésére mind a NATO, mind az Európai Unió jelentős hangsúlyt fektet, hiszen a nem, vagy nem kizárólag katonai (fegyveres) jellegü fenyegetések (például média-, kiber-, politikai, gazdasági stb.) külön-külön vagy egymással összehangolt, célirányos alkalmazása az egyes országok biztonságát súlyosan veszélyeztetheti vagy károsíthatja. A hibrid fenyegetések, támadások elleni hatékony fellépés globalizált világunkban összetett, szerteágazó feladatokat követel meg, ami felveti a valamennyi ágazatra kiterjedő, összkormányzati együttmüködés igényét. A törvénymódosítás célja ennek megfelelően, hogy törvényi szinten szabályozza és a Kormány felelösségi körébe utalja a hibrid fenyegetések elleni védelemmel kapcsolatos feladatokat, valamint az ennek alapját biztosító ellenálló képesség megteremtésének feladatait, amelyeknek a honvédelem egységes rendszerében, a honvédelmi felkészülési feladatok körében kell megjelennie. ${ }^{21}$

A hibrid fenyegetésekkel szembeni fellépés, az ellenálló képesség és a védelem definícióját a jogalkotó a jelenlegi módosítás során nem rögzítette törvényi szinten, viszont ezzel kapcsolatban feladatokat telepített a védelmi igazgatás központi és területi szintjeire, amelynek részletes vizsgálatára lentebb, a védelmi igazgatást érintő rendelkezések elemzése során kerül sor. Várhatóan a jelenlegi törvényi szintű szabályozás

\footnotetext{
2018. évi CXXV. törvény (Kit.) a kormányzati igazgatásról.

19 Sokféle megközelítés lehetséges, mint például a szabályozással érintettek köre, továbbá a szabályozás indokai, a szabályozás terjedelme, milyen jellegü módosításokra került sor, a törvény mely fejezetét érinti a változás, stb.

20 A kategorizálás a szerző saját szempontrendszere alapján történt.

21 Indokolások Tára, (2020) i. m. 10.
} 
részletszabályainak, így a hibrid fenyegetésekkel kapcsolatos rendelkezések részleteinek a kidolgozása a honvédelmi törvény végrehajtási rendeletében meg fog történni.

A katonaikibertér-műveletekkel kapcsolatos rendelkezések vonatkozásában megállapítható, hogy a NATO műveleti területnek (úgynevezett „az ötödik hadszíntér"-nek) minősítette a kiberteret, és ezzel összefüggésben kiemelten kezeli a kibertérműveleti képességek fokozatos fejlesztését. Ez a védelmi funkció azonban nemcsak a honvédelem rendszerét érinti, hanem több más ágazatot is, ezért mind az ágazatok közötti, mind pedig a kormányzati intézkedések terén szükséges az összhang megteremtése, valamint az, hogy a honvédelem területén a kibertérműveleti képességekkel összefüggő feladatmeghatározás rögzítve legyen a Kormány feladatai között. ${ }^{22}$

A katonaikibertér-múveletek vonatkozásában a szabályozás rögzíti a Honvédség katonaikibertér-műveleti erőinek feladatait, az alkalmazott intézkedések arányosságának elvét, a végrehajtásról szóló azonnali tájékoztatási kötelezettséget, továbbá meghatározza a szakmai koordinációért felelős, valamint az intézkedések végrehajtásának elrendelésére jogosult parancsnok személyét, továbbá a külföldről érkező jelentős támadás esetén szükséges eljárásrendet. Külön kitér a jogalkotó a legsúlyosabb támadások körében történő fellépés esetére, a Kormány döntési jogkörébe utalva annak megítélését. ${ }^{23}$

A Kormány feladatrendszerében a módosítások következtében rögzítették azt is, hogy meghatározza a katonaikibertér-műveleti erők védelmi, támadásmegelőzési és nemzetközi műveletekkel és felkészüléssel összefüggő feladatait, valamint az ezekkel összefüggő kivételes döntéshozatal kereteit. ${ }^{24}$

Az ország biztonságát, honvédelmi érdekeit sértő, veszélyeztető katonai jellegü kibertérműveletek, kibertérre ható cselekmények, valamint a kibertámadások elleni fellépés, illetve az ezekkel összefüggő szövetségesi, illetve nemzetközi együttmüködési keretben megvalósuló feladatok megjelennek a Honvédség feladatrendszerében is mint fegyverhasználati jog nélkül ellátandó feladatok. ${ }^{25} \mathrm{~A}$ törvény rögzíti többek között azt is, hogy ezeknek a feladatoknak a végrehajtása, továbbá a kibertérműveleti képességek fejlesztése, valamint a kapcsolódó tervezési, biztonsági és szabályozási feladatok teljesítése során a Honvédség és a Katonai Nemzetbiztonsági Szolgálat kötelesek együttmüködni egymással. ${ }^{26}$

\subsection{Az egyéb területeket érintő rendelkezések}

Ebbe a csoportba sorolhatók a honvédelem irányítási és vezetési rendszerének átalakításából adódó, az egyes jogszabályi változások következtében szükségessé váló, a különböző eljárásokkal kapcsolatos, a honvédelem szempontjából létfontosságúnak kijelölt rendszerelemekre vonatkozó, a Honvédséghez köthetö megjelölések használatával

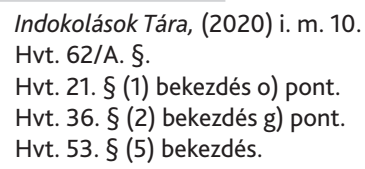


összefüggő, a korábbi hiányosságokat pótló, a technológiai fejlődés következtében szükségessé váló, a nemzetközi szintű kártérítési ügyekre vonatkozó rendelkezések.

Említést érdemel, hogy a jogalkotó új jogintézményt emelt be a törvénybe, a honvédelmi bírság jogintézményét, amelyet önálló fejezetben, a III/B. fejezetben szabályozott. ${ }^{27} \mathrm{~A}$ törvény hivatalos indokolása szerint a honvédelmi bírság jogintézményével kívánja a jogalkotó jogkövető magatartásra sarkallni a honvédelmi adatkezelésben érintetteket. A honvédelmi bírság kiszabására a fővárosi és a megyei kormányhivatal lesz jogosult, a törvényben tételesen rögzített honvédelmi feladatok végrehajtásának elmulasztásával, késedelmes teljesítésével stb. összefüggésben. Ezek alapján bírság kiszabására számíthat többek között, aki a hadkötelezettség teljesítésével összefüggésben elrendelt orvosi vizsgálatnak nem veti alá magát, vagy az a gazdasági és anyagi szolgáltatásra kötelezett, aki a kötelezettségének nem tesz eleget. A kormányhivatal az eljárását a honvédelmi adatkezelés szervének, a Honvédség katonai igazgatási és központi adatfeldolgozó szervének vagy a megyei, fővárosi védelmi bizottság honvédelmi elnökhelyettesének a kezdeményezésére folytatja le, a meghatározott szubjektív és objektív határidőkön belül. A fentiek alapján megállapítható, hogy a szabályozás arra vonatkozóan nem tartalmaz rendelkezéseket, hogy a kormányhivatalok milyen eljárásrend szerint, milyen jogszabály alapján fogják lefolytatni az eljárást, továbbá a bírság összegére vonatkozó rendelkezést sem rögzít a jogalkotó. Indokolt ezeknek a hiányosságoknak a rendeleti úton történő tisztázása. Feltételezhető, hogy a törvény végrehajtási rendelete a részletszabályok lefektetésével pótolni fogja a szabályozás hiányosságából adódó tisztázatlan kérdéseket.

Az egyéb kategóriába sorolt módosítások közül fontos kiemelni, hogy a honvédelem szempontjából létfontosságúnak kijelölt rendszerelemekre vonatkozó rendelkezések következtében a Honvédség feladatrendszerében új, fegyverhasználati joggal ellátandó feladatként határozta meg a jogalkotó a honvédelem szempontjából létfontosságúnak kijelölt rendszerelemek örzését és védelmét, ${ }^{28}$ továbbá fegyverhasználati jog nélkül ellátandó feladatként ezeknek a rendszerelemeknek a működtetésében való közremüködést. ${ }^{29} \mathrm{~A}$ törvényi szintü szabályozás egyértelmüen arra mutat rá, hogy ezeknek a rendszerelemeknek az őrzés-védelme, működtetése kiemelt jelentőségú.

Említésre érdemesek a technológiai fejlődés következtében szükségessé váló módosítások is, amelyek a különleges jogrendben elrendelhető, a közigazgatásra, közrendre és közbiztonságra vonatkozó rendkívüli intézkedések között jelennek meg. Szükséges és indokolt, hogy a sajtótermékeken és a tömegtájékoztatást szolgáló más közleményeken kívül az internetes hírportálok, valamint a közösségi médiát használó hírmegosztók előzetes ellenőrzése és a megjelenésük közzétételi engedélyhez kötése is elrendelhető legyen. A technológia rohamos fejlődése következtében szintén indokolt, hogy nemcsak a rádió, televízió és egyéb tömegkommunikációs intézmény helyiségeinek, stúdióinak, müsorszóró adóinak, berendezéseinek, létesítményeinek, hanem ezek webhelyeinek, tájékoztatást szolgáló információs rendszereinek igénybevétele, használatra való átengedése vagy ezek használatának mellőzése is elrendelhetővé

27 Hvt. 34/S. §.

28 Hvt. 36. § (1) bekezdés d) pont. Tervezetten az önkéntes területvédelmi tartalékosok egyik kiemelt feladata a kritikus infrastruktúrák védelme lesz.

29 Hvt. 36. § (2) bekezdés b) pont. 
váljon. Figyelemmel arra, hogy infokommunikációs világunkban az információs és kommunikációs csatornák múködése nélkül ellehetetlenül a társadalom és az állam mindennapi múködése, a jogalkotó új rendelkezésként emelte be a törvénybe, hogy az állami információs és kommunikációs rendszerek folyamatos üzemeltetésének biztosítása érdekében elrendelhető a javítókapacitások és alkatrészkészletek igénybevétele, vagy használatuk korlátozása, valamint a javítókapacitásokkal rendelkező társaságok tulajdonosait és munkavállalóit terhelő javítási, üzemeltetési szolgáltatás teljesítése. ${ }^{30}$

\subsection{A védelmi igazgatás, azon belül a katonai igazgatás rendszerét érintő rendelkezések}

A katonai igazgatáshoz kapcsolódó módosítások közül említésre érdemes, hogy változott, bővült a katonai szolgálatra be nem hívható hadkötelesek személyi köre. A hivatalos indokolás a honvédelmi tárca és az MH dezintegrációját emeli ki a módosítást előidéző okként, amelynek következtében szükségessé vált a honvédelmi törvényben meghatározott honvédelmi szervezeteknél állományban lévő hivatásos és szerződéses katonák, kormánytisztviselők megjelenítése annak érdekében, hogy hadkötelezettség alapján ne legyenek behívhatók katonai szolgálatra. ${ }^{31}$ A szerző véleménye ugyanakkor, hogy az új szabályozás révén tételesen meghatározott személyi kör bővebb, mint korábban volt, és a bővítés csupán a dezintegrációval nem magyarázható. A korábbi normaszöveghez képest a törvény jelenleg a honvédelmi szervezetnél állományban lévőket rögzíti a Honvédség helyett, ${ }^{32}$ a személyi kör kiegészült az önkéntes tartalékos állománnyal, valamint a közös háztartásban élő élettárs a házastárs mellett bekerült a felsorolásba. A törvény ezen bekezdése további három ponttal egészült ki, tovább bővítve a személyi kört. Nem hívható be katonai szolgálatra az a hadköteles sem, aki honvédelmi alkalmazott és a katonai szolgálat teljesítését törvény alapján önként vállalta, továbbá aki szolgálathalasztásban részesült, vagy a szolgálatát félbeszakították, a szolgálathalasztás idejének, illetve a félbeszakítás időtartamának lejártáig. Az sem hívható be, aki fegyver nélküli katonai szolgálat iránti kérelmet nyújtott be, annak végleges elbírálásáig, és aki gondnokolt személy gondnokául ki lett jelölve. ${ }^{33}$ A szerző megítélése alapján a módosítások indoka a korábbi - 2019-es - módosításban szereplő fogalmakkal való összhang megteremtése, a szabályozásnak az egyéb jogszabály-módosításokhoz történő igazítása, valamint a társadalmi viszonyok változásához való alkalmazkodás volt.

A fentiek mellett a jogalkotó egy önálló szakasznak, az 5/A. §-nak a törvénybe történt beemelésével lehetővé tette az $\mathrm{MH}$ katonai igazgatási és központi adatfeldolgozó szerve számára, hogy a behívás előkészítése és tervezése során, honvédelmi

30 Hvt. 68. § (3), (4), (5a) bekezdés.

1 Indokolások Tára, (2020) i. m. 9.

32 Hvt. 80. § 13-14. pontjában rögzített definíciók alapján a honvédelmi szervezet tágabb kategória, hiszen a Honvédségen - Magyar Honvédség Parancsnoksága, valamint alárendeltségébe tartozó katonai szervezetek - kívül a definíció alatt a honvédelemért felelős miniszter által vezetett minisztériumot, a honvédelemért felelős miniszter közvetlen alárendeltségébe tartozó szervezetet, valamint a KNBSZ-t is érteni kell.

33 Hvt. 5. § (4) bekezdés h)-i), m)-p) pontok. 
érdekből a katonai szolgálatra történő behívhatóság megállapításához szükséges mértékig bűnügyi személyes adatokat kezeljen. ${ }^{34}$

Kiemelést érdemel továbbá, hogy a módosítások következtében bővült a honvédelmi munkakötelezettség alól mentesülők köre: míg korábban csak a Honvédség, most már a honvédelmi szervezet honvédelmi alkalmazottjaira, közalkalmazottjaira, munkavállalóira, valamint a honvédelmi miniszter fenntartói irányítása alatt álló köznevelési intézmény közalkalmazottjaira és a rendvédelmi szervek munkavállalóira sem terjed ki ez a kötelezettség. ${ }^{35}$ A módosítás következtében a jogalkotói célzat némileg ellentmondásos, hiszen a honvédelmi szervezetek honvédelmi alkalmazottjai, közalkalmazottjai, munkavállalói mentesülnek a kötelezettség alól, ezzel szemben ezeknek a szervezeteknek a tényleges állományú tagjai - a Honvédségnél szolgálatot teljesítők kivételével - nem tartoznak a mentesülők személyi körébe.

A Honvédség tartalékos rendszerének egyik elemét képező kiképzett tartalékos állomány személyi körét is bővítette a módosítás. A hallgatói, honvédtisztjelölti vagy -altisztjelölti szolgálatot teljesített férfiak esetében már nem feltétel a katonai tanintézetben az alapkiképzés előzetes teljesítése a kiképzett tartalékos állományhoz tartozáshoz, továbbá újabb személyi csoportként a jogalkotó beemelte a honvédelmi szervezetnél katonai alapkiképzést, alapfelkészítést vagy annak valamely modulját teljesített férfiakat is. ${ }^{36}$ Vélelmezhetően a módosítás indoka az volt, hogy a lehető legtágabb legyen az a személyi kör, amely rendkívüli állapot vagy megelőző védelmi helyzet idején a hadkötelezettség bevezetését követően tényleges katonai szolgálatot teljesíthet.

A védelmi igazgatás szervezet- és feladatrendszerét érintő módositásokat elemezve megállapitható, hogy az egyik legfontosabb, a szabályozás szükségességét igénylő terület a hibrid fenyegetésekkel szembeni fellépésre vonatkozó szabályozás megteremtése volt. A hibrid fenyegetésekkel szembeni ellenálló képesség és védelem feladatai a védelmi igazgatás központi szintjén, irányítási szinten valamennyi szervnél megjelennek, továbbá területi szinten, az igazgatás szintjén a megyei védelmi bizottságokra is telepít ezzel kapcsolatos feladatokat a jogalkotó.

Az irányítás szintjét vizsgálva megállapítható, hogy a törvény új feladatként a Kormányhoz telepíti a hibrid fenyegetésekkel szembeni ellenálló képesség és védelem feladatainak meghatározását. ${ }^{37} \mathrm{~A}$ hibrid fenyegetések összetett, szerteágazó volta miatt az ellenük való hatékony fellépés elképzelhetetlen együttmüködés és koordináció nélkül. Ez a gondolat jelenik meg a honvédelmi miniszter feladatkörét érintő módosításokban is. A honvédelmi miniszter feladatai kiegészültek a polgári felkészültséggel kapcsolatos feladatok végrehajtásának koordinációjával, továbbá plusz elem, hogy ezeket a feladatokat a honvédelmi miniszter a belügyminiszter tájékoztatása mellett végzi. ${ }^{38}$

Az érintett miniszterek szintjén is megjelenik a terület szabályozása, amikor a törvény rögzíti, hogy a miniszter a honvédelemi miniszterrel együttmüködve biztosítja

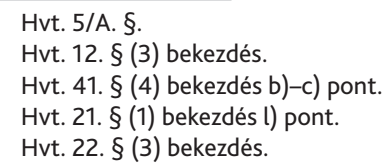


a hibrid fenyegetések elhárítása érdekében meghatározott feladatokat. ${ }^{39}$ A hibrid fenyegetések (támadások) lényegi voltából - az ország védelmét oly módon veszélyeztetik, hogy katonai és nem katonai eszközöket egyaránt alkalmaznak - adódóan indokolt az érintett minisztereknek a honvédelmi miniszterrel történő együttmüködése. ${ }^{40}$

A központi irányítás szerveire vonatkozó módosításokat vizsgálva megállapítható, hogy a szabályozás nem tekinthető koherensnek: a hibrid fenyegetésekkel szembeni feladatok rögzítése megfigyelhető a Kormány és az illetékes miniszterek vonatkozásában, azonban a jogalkotó a honvédelmi miniszter feladatrendszerébe azokat nem telepíti, a honvédelmi miniszter feladatai között „csupán” a hibrid fenyegetésekkel összefüggésben a polgári felkészültséggel kapcsolatos feladatok végrehajtásának koordinációját rögzítették. A jogalkotó területi szinten, a megyei védelmi bizottságokra vonatkozó szabályozás során már mindkét fogalommal operál, amikor rögzíti, hogy a megyei védelmi bizottság összehangolja a hibrid fenyegetések elleni védelem, valamint a polgári felkészültség területi feladatait. ${ }^{41}$

$A$ védelmi igazgatás területi, helyi szintjeire vonatkozó módosítások elemzését megelőzően a védelmi igazgatás települési szintjén, a polgármesterekre vonatkozó rendelkezéseket vizsgálva kiemelést érdemel, hogy sor került a polgármester vonatkozásában annak törvényi szintű rögzítésére, hogy a törvényben tételesen felsorolt feladatait honvédelmi igazgatási jogkörben látja el.

Ezen túl két, a polgármester hatáskörébe utalt feladat esetében is erősödött a polgármester jogköre. A korábbi szabályozás szerint összehangolta a honvédelemben közremüködő települési szervek tevékenységét, a hatályos törvényszöveg alapján már megszervezi ezt a tevékenységet. Míg korábban közremüködött a gazdaságfelkészítés és -mozgósítás helyi feladatainak szervezésében és ellátásában, addig a hatályos szabályozás szerint irányítja az ezzel kapcsolatos feladatokat. Ezek mellett a feladatok mellett a hatáskörébe utalt, a fegyveres összeütközések időszakában végrehajtandó polgári védelmi feladatok ellátásának és az azokra történő felkészülésnek az irányítása vonatkozásában a korábbi szabályozáshoz képest a tételes felsorolásban megjelent a honvédelmi veszélyhelyzet is, mint az az időszak, amikor ez a feladatellátás szükségessé válhat. A törvény a polgármester jogkörébe telepíti a honvédelmi referens személyének kijelölését, amely új jogintézményként jelenik meg. ${ }^{42}$

További változás, hogy a polgármester a honvédelmi törvény szerint a honvédelmi felkészítéssel kapcsolatos feladatok teljesítése érdekében volt köteles együttmüködni a helyi védelmi bizottság rendelkezései szerint más települések polgármestereivel, a módosítások következtében azonban már nemcsak a honvédelmi felkészítéssel kapcsolatos, hanem a honvédelmi igazgatási jogkörében ellátandó feladatok vonatkozásában is köteles lesz az együttmüködésre más települések polgármestereivel és a fővárosi kerületek polgármestereivel is, ami szintén új elem a rendelkezésben. ${ }^{43}$

Míg korábban a polgármester a védelmi igazgatási feladatait a járási hivatal közremúködésével látta el, addig a hatályos szabályozás szerint jelenleg mindezt

39 Hvt. 23. § (2) bekezdés bd) pont.

40 Indokolások Tára, (2020) i. m. 10.

41 Hvt. 26. § (1) bekezdés b) pont.

42 Hvt. 29. § (2) bekezdés.

43 Hvt. 29. § (3) bekezdés. 
a polgármesteri hivatal közreműködésével teszi. ${ }^{44}$ ( $\mathrm{A}$ járási hivatal a hatályos szabályozás alapján a helyi védelmi bizottság munkáját segíti.) A polgármester feladat- és jogkörét érintő módosítások a polgármester jogkörének erősítését célozzák, amely a rá vonatkozó szélesebb körű együttmüködési kötelezettséggel indokolt lehet a települési szintű feladatok hatékonyabb végrehajtásához. Azzal, hogy a jogalkotó a járási hivatal helyett a polgármester mellett a védelmi igazgatási feladatok ellátásában a polgármesteri hivatalt jelölte meg, koherenciát teremtett, amely illeszkedik az államigazgatás struktúrájához, közreműködőként azonos szintű szerveket egymás mellé rendelve.

Itt kell megemlíteni továbbá, hogy a törvény bevezette a honvédelmi referens intézményét, amelynek definícióját a jogalkotó az értelmező rendelkezések között rögzítette. A referensi tisztséget betöltő személy a polgármestert segítő személy, akit a polgármester jelöl ki, a honvédelmi törvény végrehajtási rendeletében meghatározott iskolai végzettséggel kell rendelkeznie, és a polgármester honvédelmi felkészülési és védekezési szakmai feladataiban müködik közre ${ }^{45} \mathrm{~A}$ normaszöveg egyéb feltételt nem tartalmaz, ezért a meghatározás alapján az állapítható meg, hogy minden település polgármesterének honvédelmi feladatait szakmailag a honvédelmi referens fogja segíteni. Felmerül azonban a kérdés, hogy valamennyi polgármester - a legkisebb települések esetén is - mellett szükséges és indokolt-e ilyen tisztséget betöltő személyt foglalkoztatni? Feltételezhetően, a módosítás előtt álló végrehajtási rendeletben sor kerül a részletszabályok kidolgozásával a felmerülő kérdések tisztázására.

A védelmi igazgatás feladatrendszere vonatkozásában kiemelendő továbbá, hogy a jogalkotó törvényi szinten, önálló új fejezet, a III/C. fejezet alatt „A nemzetgazdaság védelmi célú felkészítése és a gazdaságmozgósítás" címmel rögzítette a vonatkozó alapvető rendelkezéseket, ezzel korábbi hiányosságokat pótolva. A nemzetgazdaság védelmi célú felkészítésével kapcsolatosan a jogalkotó meghatározta annak alapvető elemeit, a tervezési folyamatot, a védelmi célú tartalékolás rendszerének müködtetését, valamint a gazdaság mozgósítását. A tervezési folyamat részeként előírta a védelemgazdasági alapterv, a védelemgazdasági tervek, valamint a lakosságellátási tervek elkészitését. A tervek elkészitésének felelőseit, a jóváhagyásra jogosult szervet, valamint az alapvető követelményeket szintén rögzítette a jogalkotó. A védelmi célú tartalékolás vonatkozásában tételes felsorolást adott az ország védelmi célú tartalékát képező termékekről, eszközökről, készletekről. A szabályozás a Kormány hatáskörébe utalta a kapcsolatos részletszabályok kidolgozását és a szükséges költségvetési források biztosításának feladatát. ${ }^{46}$

A gazdaságmozgósításra vonatkozó rendelkezések között fontos kiemelni, hogy a gazdaságmozgósítás értelmező rendelkezések között meghatározott definíciójában számos módosítás történt. A korábbi törvényszövegben - a fogalom egyik meghatározó elemeként -szerepelt „a Kormány által elrendelhető intézkedések rendszere” kitétel, a hatályos szabályozás szerint viszont a gazdaságmozgósítás a Kormány irányításával, a védelemgazdasági alaptervben, a védelemgazdasági tervekben és a lakosságellátási tervekben meghatározottak szerint, a honvédelem területi és helyi igazgatási szerveinek

\footnotetext{
Hvt. 29. § (4) bekezdés.

45 Hvt. 80. § 16a. pont.

46 Hvt. 34/T-U. §.
} 
közremüködésével végzett tevékenysége. Megállapitható, hogy a jelenlegi meghatározásból kimaradt az alany, a törvény szövege nem határozta meg, hogy ez kinek, milyen szervnek a tevékenysége, csupán azt rögzíti, hogy mely szerv irányításával és mely szervek közremüködésével, milyen tervekben meghatározottak alapján kell végezni a tevékenységet, anélkül, hogy a tevékenység végzésére kötelezett szerv/személy nevesítve lenne. A korábbi definíció meghatározta, hogy a gazdaságmozgósítás a nemzetgazdasági erőforrások szabályozott igénybevételét jelenti, valamint „a különleges jogrendi időszak, az országvédelmi feladatok hatékony kezelése érdekében" szófordulatokkal rögzítette azt is, hogy erre az igénybevételre mely esetekben, milyen időszakokban kerülhet sor. A módosítás következtében a hatályos normaszöveg továbbra is tartalmazza azt, hogy mely esetekben kerülhet sor a gazdaság mozgósítására - a különleges jogrend, valamint az országvédelmi feladatok hatékony kezelése érdekében-, azonban a meghatározásból hiányzik az „igénybevétel” szó, ezáltal a definíció elején szereplo „a nemzetgazdaság erőforrásainak” kifejezés értelmét veszíti. ${ }^{47}$ Mindezek alapján megállapítható, hogy a definíció a fentebb ismertetett hiányosságok folytán nem tartalmaz egyértelmü, világos meghatározást, valószínüsíthetően a kidolgozás alatt álló végrehajtási rendelet pótolja majd ezeket a hiányosságokat.

A fogalom módosítása mellett a gazdaságmozgósításra vonatkozóan a jogalkotó meghatározta többek között - annak a Kormány általi elrendelését követően - a gazdasági és anyagi szolgáltatásra kötelezettek, a felelős teljesítő szervek, a követelménytámasztó szerv, a feladat- és hatáskörrel rendelkező miniszter alapvető kötelezettségeit is. ${ }^{48}$

\subsection{A védelmi igazgatás területi és helyi szerveit, a megyei és a helyi védelmi bizottságokat érintő módosítások}

A megyei védelmi bizottságok vonatkozásában megállapítható, hogy a bizottságok szervezeti rendszere a törvénymódosítás következtében átalakult. A megyei védelmi bizottság eddigi két szakmai elnökhelyettese mellett megjelent egy harmadik, általános elnökhelyettes a fővárosi/megyei kormányhivatal főigazgatója személyével, ${ }^{49}$ továbbá a szakmai elnökhelyettesek és a tagok vonatkozásában is megfigyelhetök változások. Az általános elnökhelyettesi tisztség létrehozásának indoka a 2018. évi CXXV. törvény ${ }^{50} 41$. § (3) bekezdésével való összhang megteremtése volt, amely szerint a kormánymegbízott általános helyettese a főigazgató. ${ }^{51}$

A szakmai elnökhelyettesek vonatkozásában is eszközölt változtatásokat a jogalkotó. A két szakmai elnökhelyettes egyike, a honvédelmi elnökhelyettes már nem a Honvédség állományába tartozó tényleges állományú katona, hanem a honvédelmi miniszter által kijelölt tényleges állományú katona. ${ }^{52} \mathrm{~A}$ honvédelmi törvény végrehajtási

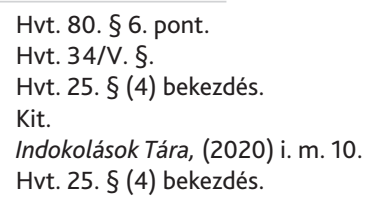


rendelete, a 290/2011. (XII. 22.) Korm. rendelet ${ }^{53}$ 23. § (4) bekezdése szerint azonban a honvédelmi elnökhelyettes a HM védelmi igazgatási feladatokat ellátó szervezeti egységének vezetője vagy az általa kijelölt személy. A jogszabályi ellentmondások feloldása a végrehajtási rendelet átdolgozásával vélhetően meg fog történni.

A tagok személyében bekövetkezett változásokat vizsgálva megfigyelhetö, hogy a korábbi szabályozás szerint nemcsak a katonai igazgatás területi szervének vezetője, hanem annak képviselője is tag lehetett. Korábban tag volt a megyei, fővárosi rendőrfőkapitány, míg a hatályos törvényszöveg szerint a módosítások folytán a bizottság illetékességi területén müködő rendvédelmi szerv - tehát nemcsak a rendőrség - illetékes vezetője tagja a bizottságnak. A módosítást megelőzően tag volt a vízügyi igazgatási szerv képviselője, jelenleg az árvízi védekezésért felelős szervezet vezetőjét jelöli meg a törvény a bizottság tagjaként. Továbbá a 2020. január 1-je előtti szabályozás alapján a bizottság titkára is a tagok közé tartozott, a hatályos szabályozás szerint azonban már nem tagja a bizottságnak..$^{54}$ A módosítások közül megkérdőjelezhető, hogy valóban szükség van-e a bizottsági üléseken valamennyi, a bizottság illetékességi területén működő rendvédelmi szerv vezetőjének a részvételére. Vélhetően, a tagokra vonatkozó szabályozás részleteit a végrehajtási rendelet rögzíteni fogja.

A megyei védelmi bizottságok feladatrendszerét érintő módosításokat elemezve megállapítható, hogy új feladatként jelenik meg a hibrid fenyegetések elleni védelem, valamint a polgári felkészültség területi feladatainak összehangolása. A meglévő feladatok között is történtek változtatások. Korábban a helyi védelmi bizottságok és a polgármesterek honvédelmi tevékenységének irányítása tartozott a bizottság feladatai közé, a hatályos szabályozás szerint a polgármesterek honvédelmi tevékenységének irányítása a helyi védelmi bizottságokon keresztül történik. ${ }^{55} \mathrm{~A}$ korábban kifejtettek alapján jól látható, hogy a hibrid fenyegetések elleni fellépéssel kapcsolatos feladatok a védelmi igazgatás központi szintjétől kezdődően egészen a területi szintig megjelentek. A polgármesterek honvédelmi tevékenységének a helyi védelmi bizottságokon keresztül történő irányítása vonatkozásában indokolt volt a jogalkotó részéröl a módosítás, hiszen a módosított rendelkezéssel a védelmi igazgatás struktúrájához igazodó irányítási rendszert teremtett.

A nemzetgazdaság védelmi célú felkészítésére vonatkozó új törvényi szintú szabályozás a felkészítés egyik elemeként jelöli a tervezési folyamatot, amelyben a megyei védelmi bizottságokra is feladatot telepít. A bizottságok illetékességi területükre vonatkozóan kötelesek lakosságellátási tervet készíteni, amelyet a bizottság elnöke hagy jóvá. ${ }^{56}$

A bizottság elnökére vonatkozó megváltozott rendelkezések közül kiemelendő, hogy a 2020. január 1-jét megelőző szabályozás az elnök védelmi igazgatási feladatait rögzítette, míg a hatályos törvény a honvédelmi igazgatási feladatok kifejezést alkalmazza, amely feladatokat a fővárosi, megyei kormányhivatal közremüködésével

53 290/2011. (XII. 22.) Korm. rendelet a honvédelemröl és a Magyar Honvédségröl, valamint a különleges jogrendben bevezethető intézkedésekről szóló 2011. évi CXIII. törvény egyes rendelkezéseinek végrehajtásáról.

54 Hvt. 25. § (4) bekezdés c)-f) pont.

55 Hvt. 26. § (1) bekezdés a)-b) pont.

56 Hvt. 34/T. § (4) bekezdés. 
lát el ${ }^{57} \mathrm{~A}$ módositás a szerző álláspontja szerint bizonytalan helyzetet teremt azáltal, hogy a kormányhivatal közreműködését a honvédelmi igazgatási feladatokra korlátozza. Felmerül a kérdés, hogy az elnök a honvédelmi igazgatási feladatain kívüli egyéb, védelmi igazgatási feladatait a későbbiekben milyen szerv közreműködésével fogja ellátni, ha nem a fővárosi, megyei kormányhivatal segítségével?

Egy, a fentebb kifejtett új jogintézményre, a honvédelmi bírság intézményére vonatkozó szabályozás szintén kapcsolódik a megyei védelmi bizottságokhoz, hiszen új rendelkezésként a jogalkotó rögzítette, hogy a honvédelmi bírság kiszabásával kapcsolatos eljárás kezdeményezésére jogosult - többek között - a megyei, fővárosi védelmi bizottság honvédelmi elnökhelyettese is. ${ }^{58}$

A helyi védelmi bizottságok felépítését, feladatrendszerét illetően is módosult a szabályozás. A bizottságok struktúráját tekintve kisebb mértékủ változások figyelhetők meg, hiszen a megyei védelmi bizottságoknál megjelenő általános elnökhelyettesi rendszert a jogalkotó a helyi védelmi bizottságoknál nem alakította ki, ezáltal a megyei és helyi védelmi bizottságok korábbi egyező struktúrája megszünt. Az elnökhelyettesekre vonatkozó rendelkezések annyiban változtak, hogy a hatályos törvény az elnökhelyettesek vonatkozásában rögzíti a „szakmai” jelzőt. Az egyik szakmai elnökhelyettes, a honvédelmi elnökhelyettes a Honvédség állományából vezényelt katona. ${ }^{59} \mathrm{~A}$ korábbi normaszöveg szerint a honvédelmi elnökhelyettes a Honvédség állományából szükség esetén vezényelt tényleges állományú katona volt, ezáltal a hatályos törvényszövegből kimaradt a "szükség esetén" vezényelt és a „tényleges állományú" kitétel, amellyel a jogalkotó bővítette a honvédelmi elnökhelyettesi tisztséget betölteni alkalmas katonák személyi körét.

A tagokra vonatkozó módosítás alapján megállapítható, hogy bővült a helyi védelmi bizottság tagjainak száma az árvízi védekezésért felelős szervezetnek a bizottság illetékességi területe szerinti vezetője személyével. ${ }^{60}$ Hasonlóan a megyei védelmi bizottság tagjainak összetételéhez, a helyi védelmi bizottságok szintjén is szükségesnek tartotta a jogalkotó a tagok között az árvízi védekezésért felelős szervezet képviseletét, tekintve, hogy Magyarországon a vízrajzi adottságok következtében jelentős veszélyforrást jelentenek az árvizek. A helyi védelmi bizottságok esetében a titkár továbbra is a bizottság szavazati joggal rendelkező tagja, míg a megyei védelmi bizottságok esetében már nem tag a hatályos szabályozás szerint. Ez utóbbi módosítás szintén a megyei és a helyi védelmi bizottságok eltérő strukturáltságának irányába hatott.

A helyi védelmi bizottság elnöke vonatkozásában kiegészült a törvény szövege azzal a rendelkezéssel, hogy az elnök védelmi igazgatási feladatait a járási hivatal közremüködésével látja el. ${ }^{61} \mathrm{~A}$ törvény módosítás előtt álló végrehajtási rendelete, a 290/2011. (XII. 22.) Korm. rendelet 32. § (1) bekezdése szerint az elnököt védelmi igazgatási feladatai ellátásában a járási hivatal javaslattevő, döntés-előkészítő jogkörrel segíti, és közremüködik a döntések végrehajtásában. A módosítás következtében, amelyet törvényi szinten rögzítettek, már mindenfajta feladat ellátása a hivatal

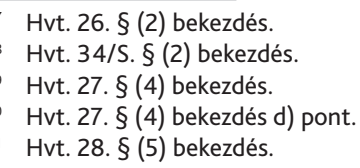


közremúködésével történik, amely nagyobb szintű együttmüködést feltételez. Várhatóan a végrehajtási rendelet vonatkozó rendelkezéseit módosítani fogják majd.

Fontos megjegyezni, hogy míg a megyei védelmi bizottság esetében az elnök a honvédelmi igazgatási feladatait a fővárosi, megyei kormányhivatal közremüködésével látja el, addig a helyi védelmi bizottság elnöke a járási hivatal közremüködésével a védelmi igazgatási feladatait végzi. A fentiekből kitünik, hogy a módosítások megszüntették a koherens szabályozást, amelynek újbóli megteremtése remélhetőleg a végrehajtási rendelet módosított rendelkezéseivel meg fog történni.

\section{Befejezés}

A honvédelmi törvény 2020. január 1-jén hatályba lépett módosításait elemezve megállapítható, hogy a jogalkotó az aktuálisan felmerült és szabályozást igénylő kérdéskörökre reagált a változtatásokkal. A hibrid fenyegetésekkel szembeni fellépéssel kapcsolatos feladatok rögzítése a NATO elvárásai alapján, illetve tagállami elkötelezödésünk alapján is időszerü és szükségszerű volt. Hasonlóképpen a kiberfenyegetésekkel szemben is szükségessé vált törvényi szinten a válaszadás, továbbá a kritikusinfrastruktúra-védelem, a honvédelem vezetési-irányítási rendszerének 2019. évben történt átalakítása, az egyéb jogszabályokkal való összhang megteremtése, a technológiai fejlődésből adódó, valamint a korábbi szabályozási hiányosságokat rendező, kollíziókat megszüntető szabályozási szükségszerűségek is indokolták a törvény módosítását.

A változások a védelmi igazgatás, azon belül a megyei és helyi védelmi bizottságok szervezet- és feladatrendszerét is érintették. A védelmi igazgatás központi és területi szintjén megjelentek a hibrid fenyegetésekkel összefüggő feladatok, továbbá a nemzetgazdaság védelmi célú felkészítéséből és a gazdaságmozgósításból adódó feladatok szintén megjelentek a védelmi igazgatás szereplőinek feladatrendszerében. A polgármester feladat- és jogkörét érintő módosítások is megfigyelhetők a törvényben, amelyek a polgármester jogkörének erősítését célozzák, egyben szélesebb körú együttmúködési kötelezettséget rögzítenek. Ezek a módosítások alkalmasak arra, hogy hozzájáruljanak a polgármester települési szintű feladatainak hatékonyabb végrehajtásához. Azzal, hogy a jogalkotó a járási hivatal helyett a polgármester mellett a védelmi igazgatási feladatok ellátásában a polgármesteri hivatalt jelölte meg, koherenciát teremtett, amely illeszkedik az államigazgatás struktúrájához, közremüködőként azonos szintű szerveket egymás mellé rendelve. A polgármester munkáját segítendő bevezette a törvény a honvédelmi referens intézményét, azonban indokolt a vonatkozó szabályozás részletes kimunkálása, a szabályozás kapcsán felmerült bizonytalanságok eloszlatása, amely várhatóan a honvédelmi törvény végrehajtási rendeletének átdolgozásával meg fog történni.

A honvédelmi törvény módosításai a megyei és a helyi védelmi bizottságok szervezeti és feladatrendszerében is változásokat hoztak. A bizottságok felépítését illetően a módosítások - a megyei védelmi bizottságoknál megjelenő általános elnökhelyettesi tisztség megjelenésével, valamint a titkár tagi minőségének megszűnésével - az eltérő strukturáltság irányába hatottak. A feladatrendszer vonatkozásában a megyei védelmi bizottságok feladatai között megjelenítette a jogalkotó a hibrid fenyegetésekkel 
szembeni fellépésből származó feladatokat, valamint a lakosságellátási terv készítésének kötelezettségét. A helyi védelmi bizottságok, illetve azok elnökeinek szerepét erősítendő a törvény rögzítette, hogy az elnök valamennyi védelmi igazgatási feladatát a járási hivatal közremüködésével látja el, továbbá azt, hogy a megyei védelmi bizottság a polgármesterek honvédelmi tevékenységének irányítását a helyi védelmi bizottságokon keresztül végzi. Ez utóbbi rendelkezés indokolt volt a jogalkotó részéről, hiszen a módosított rendelkezéssel a védelmi igazgatás struktúrájához igazodó irányítási rendszert teremtett. Ugyanakkor megszüntette a koherenciát a jogalkotó azzal, hogy a módosítás következtében a megyei védelmi bizottság elnöke a honvédelmi igazgatási feladatokat látja el a fővárosi, megyei kormányhivatal közremüködésével, míg a helyi védelmi bizottság elnöke valamennyi védelmi igazgatási feladatát a járási hivatal közremüködésével teljesíti. A módosítás azért is aggályos, mert a törvény a kormányhivatal közremüködését a honvédelmi igazgatási feladatokra korlátozza, ezáltal bizonytalan helyzetet teremtve a honvédelmi igazgatási feladatokon kívüli egyéb, védelmi igazgatási feladatok vonatkozásában.

Mindezek alapján megállapítható, hogy a honvédelmi törvény módosításai a felmerült szabályozási igényeknek megfelelően számos területen, számos szerv vonatkozásában változásokat eredményeztek, új jogintézményeket vezettek be, korábban nem szabályozott kérdésekre vonatkozóan, illetve egyes területeken korábbi hiányosságokat pótolva, kollíziókat megszüntetve teremtették meg a szabályozás törvényi alapjait. A módosítások kapcsán felmerült bizonytalanságok, hiányosságok pótlására valószínüsíthetően a jogalkotó a törvény végrehajtási rendeletében fogja megadni a válaszokat.

\section{Felhasznált irodalom}

Hornyacsek Júlia: A védelmi igazgatási feladatok rendszere, a végrehajtás személyi, technikai feltételei, lehetséges módszerei, eszközei. In Hornyacsek Júlia (szerk.): A védelmi igazgatás müködésének gyakorlati tapasztalatai napjaink kihívásainak tükrében. Budapest, Dialóg Campus, 2019. 87-99.

Indokolások Tára, (2020), 2. 6-20.

Keszely László: A védelmi igazgatás fejlődési irányai 1989-től napjainkig és lehetséges fejlesztési irányai az átfogó megközelítés szempontjából. In Hornyacsek Júlia (szerk.): A védelmi igazgatás rendszere és a honvédelmi igazgatással való kapcsolatának elméleti és gyakorlati összefüggései. Budapest, Dialóg Campus, 2019. 9-28. Lakatos László: A honvédelmi típusú különleges jogrendek életbeléptetését igénylő helyzetek és azok korszerü gyakorlati megoldása. In Hornyacsek Júlia (szerk.): A védelmi igazgatás müködésének gyakorlati tapasztalatai napjaink kihívásainak tükrében. Budapest, Dialóg Campus, 2019. 37-60.

Magyar Közlöny, (2019), 205.

Muhoray Árpád: A katasztrófavédelem hivatásos és civil ágának fejlődése, feladatai a védelmi igazgatásban. In Hornyacsek Júlia (szerk.): A védelmi igazgatás fö területeinek változásai az elmúlt időszakban, és a fejlesztés lehetséges irányai. Budapest, Nemzeti Közszolgálati Egyetem, 2019. 59-71. 


\section{Internetes források}

A honvédelmi törvényt módosító T/8029. számú törvényjavaslat. Online: www. parlament.hu/irom41/08029/08029.pdf

A honvédelmi törvény módosítása. Online: www.parlament.hu/web/guest/szavazasok-egy-adott-iromanyrol?p_p_id=hu_parlament_cms_pair_portlet_PairProxy_ INSTANCE_9xd2Wc9jP4z8\&P_P_lifecycle=1\&P_P_state=normal\&P_P_mode =view\&p_auth=GpETUHgk\&_hu_parlament_cms_pair_portlet_PairProxy_ INSTANCE_9xd2Wc9jP4z8_pairAction=\%2Finternet\%2Fcplsql\%2Fogy_irom. irom_adat\%3Fp_ckl\%3D41\%26p_izon\%3D8029

NATO: Warsaw Summit Communiqué. (Varsói csúcstalálkozó közleménye az Északatlanti Tanács 2016. július 8-9-én tartott ülésén.) Online: www.nato.int/cps/ en/natohq/official_texts_133169.htm

NATO: Commitment to enhance resilience. (Az állam- és kormányfőknek az Északatlanti Tanács 2016. július 8-9-én Varsóban tartott ülésén tett nyilatkozata az ellenálló képesség fokozása iránti elkötelezettségükről.) Online: www.nato. int/cps/en/natohq/official_texts_133180.htm

Nyulas Szabolcs: Új alapok, tiszta viszonyok a Magyar Honvédség vezetésében. Honvédelem, 2019. Online: https://honvedelem.hu/cikk/uj-alapok-tiszta-viszonyok-a-magyar-honvedseg-vezeteseben/

NATO: The Secretary General's Annual Report. (A NATO fötitkár 2018. évi jelentése.) 2018. Online: www.nato.int/nato_static_fl2014/assets/pdf/pdf_publications/20190315_sgar2018-en.pdf

\section{Jogi források}

2011. évi CXIII. törvény a honvédelemröl és a Magyar Honvédségröl, valamint a különleges jogrendben bevezethető intézkedésekröl

2012. évi CLXVI. törvény a létfontosságú rendszerek és létesítmények azonosításáról, kijelöléséről és védelméröl

2018. évi CXXV. törvény a kormányzati igazgatásról

290/2011. (XII. 22.) Korm. rendelet a honvédelemröl és a Magyar Honvédségröl, valamint a különleges jogrendben bevezethető intézkedésekröl szóló 2011. évi CXIII. törvény egyes rendelkezéseinek végrehajtásáról 